\title{
Pomato: Double Harvest from a Single Plant
}

\author{
Siddikul Islam ${ }^{1}$, Sk Isa Hoque ${ }^{1}$, Suchand Datta ${ }^{2}$, \\ Ranjit Chatterjee ${ }^{3}$ and Prahlad Sarkar ${ }^{4}$
}
${ }^{1}$ Dakshin Dinajpur KVK, Uttar Banga Krishi Viswavidyalaya, Majhian, West Bengal, India, ${ }^{2}$ Regional Research Station, Terai Zone, ${ }^{3}$ Vegetable and Spice Crops, ${ }^{4}$ All India Network Project on Jute and Allied Fibres, Uttar Banga Krishi Viswavidyalaya, Pundibari, Cooch Behar, West Bengal, India

*Corresponding author

\begin{abstract}
Keywords
Grafting, Pomato,

Potato, Tomato,

Yield

Article Info

Accepted:

15 March 2019

Available Online:

10 April 2019 DDKVK Majhian. 30 days old tomato seedlings were cleft grafted in a 20 days old potato seedling. Successful graft union was achieved after 15 days of grafting. The grafted plants produced profuse branches and flowers. Mature fruits were ready to start harvest in about 110 days after grafting and harvesting was continuing up to 150 days. The result also showed that average fruits per plant in tomato were 35, average fruit weight 78 gram and an individual plant produce about 2729.79 gram fruits. Edible potato tubers were ready to harvest at 120 days after grafting and yielding about 4-5 number of potato around 211 gram tuber from each plant. Though the experiment was conducted just as aesthetic interest to show whether the graft succeeds or not. But after the completion of the programme, it may be suggested that any home gardener can practice this technique as an amazing satisfaction which may fulfill home requirement to some extend for both tomato and potato. However, it may require further study for commercialization of the technique in large scale.
\end{abstract}

A B S T R A C T

Pomato is a grafted plant developed by grafting tomato and potato with an objective to achieve both potato and tomato yield from a single plant. In the present study grafting between tomato and potato was done during November, 2017 at the research field of

\section{Introduction}

Vegetable cultivation is an important scope to improve the socio-economic condition of marginal and small farmer as demand of vegetable increasing day by day due to changing food habits of people, balanced diet concept for nutritional security, more yields per unit area and fetch more prices per unit area of vegetables. So, vegetables are more economical to grow. Both Tomato (Lycopersicon esculentum Mill.) and potato (Solanum tuberosum L.) are most important solanaceous high value vegetables commercially grown in India for its usefulness as well as economical and nutritive value. India stands second in position in the world in respect of production of tomato and 
potato and produces 22.34 and 50.32 metric tonnes respectively for the year 2017-18 which were cultivated throughout the India where West Bengal contributed 5.66 and 24.50 percent share of total production (Anonymous, 2018). Cultivation of multiple vegetables in a single unit of land is another way to overcome marketing problem and more outcomes.

Climate change and urbanization along with bombasting population are force to shift agriculture in a changing situation. Modification of an existing system is a common practice to adopt in changing environmental situation. In India at present farmers are shifted in modified agriculture from traditional one for sustainable production. Grafting of vegetable is a unique strategy to overcome some difficult problem related to intensive vegetable cultivation using limited land. At first it was adapted by Japan and Korea and later by many countries in Europe, Northern Africa, Central America and other parts of Asia. In India, vegetable grafting has been started in different states of India.

The vegetable grafting is an alternative strategy to overcome some important hindrance related to vegetable production such as bacterial wilt, fusarium wilt, nematodes, high and low temperature, flood, site specific adaptability, fruits durability etc. Kubota et al., (2008) recorded that in North America using some particular rootstocks soil borne diseases and nematodes problem was overcome and increase yield. Pomato is a single plant artificially created by grafting of tomato in potato which has capability to produce both tomato and potato. Both the crops have a great demand in the daily life of Indian people and production is not increased so far as per population growth. Kumar et al., (2015) reported that combination of scion and rootstock were greatly influenced growth, yield and fruit quality and applying grafting techniques resistance against low and high temperatures can be induced and improves quality of the plant. They also recorded that high post graft mortality of seedlings was occurred and still in infancy in India and improvement of grafting skills and healing environmental condition need to be standardized. Considering the point along with aesthetic interest present study was undertaken with the objectives of to see performance of grafting between tomato and potato, yield of tomato and potato from pomato in a same time, commercialization ability of the techniques.

\section{Materials and Methods}

The present study on vegetable grafting was done during November, 2017 at the research field of Dakshin Dinajpur Krishi Vigyan Kendra, Majhian under Uttar Banga Krishi Viswavidyalaya. In this experiment Avinash2 variety of tomato and Kufri Jyoti variety of potato were used as scion and rootstock respectively. About 4 square meters of wellprepared main land was used to sowing potato and tomatoes scion were grafted on it. The seed tubers of potato were sown 5-7 days before the tomato seeds in a well-prepared land. Tomato seedlings were raised in portray using well rotten farm yard manure and vermi-compost. The end portion of 30 days old seedlings of tomato (scion) were cut into wedge shaped and 20 days old potato stem (rootstock) were cut at right angles, and fitted both rootstock and scion in properly as cleft graft. Thickness of both rootstock and scion were same as pencil. After setting of the graft tied properly with a plastic clip. This process was done during the afternoon session of the days. Care had been taken during grafting so that xylem and phloem of both the root stock and scion were attached properly. Observation were taken about percentage of successful grafting, days taken for both 
tomato and potato yield, number of fruits and tuber per plant, yield per plant. Data for all the parameters were taken as average of five plants.

\section{Results and Discussion}

As both the crops belongs to same family plant, the grafting between tomato and potato became success which was about 62 percent and the graft union took 12-15 days to grow successfully. The grafting concept between potatoes and tomatoes was actually introduced in 1977 at the Max Planck Institute for Developmental Biology in Tubingen, Germany and successfully tomato fruit and potato tuber were produced in 1994 at the Max Planck Institute for Plant Breeding Research in Cologne (Reinhard, 2008). The grafted pomato plant already commercially introduced in the United Kingdom named as "Tom Tato" (David, 2013). The plant which was side branches of potato rootstock shown lower growth rate compared to branchless plant as more nutrients were supplied to the shoots of rootstock (Table 1 and 2).

Table.1 Numbers of fruits, average fruits weight, total weight of fruits per plant in tomato of pomato plant

\begin{tabular}{|l|c|c|c|}
\hline $\begin{array}{c}\text { Plant } \\
\text { no. }\end{array}$ & $\begin{array}{c}\text { Number of fruits } \\
\text { per plant }\end{array}$ & $\begin{array}{c}\text { Average fruits } \\
\text { weight }(\mathbf{g})\end{array}$ & $\begin{array}{c}\text { total weight of fruits } \\
\text { per plant }(\mathbf{g})\end{array}$ \\
\hline $\mathbf{1}$ & 33 & 79.5 & 2623.50 \\
\hline $\mathbf{2}$ & 36 & 78 & 2808.00 \\
\hline $\mathbf{3}$ & 39 & 81 & 3159.00 \\
\hline $\mathbf{4}$ & 37 & 74 & 2738.00 \\
\hline $\mathbf{5}$ & 32 & 79.5 & 2544.00 \\
\hline $\mathbf{6}$ & 34 & 82.45 & 2803.30 \\
\hline $\mathbf{7}$ & 34 & 71.55 & 2432.70 \\
\hline Average & $\mathbf{3 5}$ & $\mathbf{7 8}$ & $\mathbf{2 7 2 9 . 7 9}$ \\
\hline
\end{tabular}

Table.2 Numbers of tubers and total weight of tuber per plant in potato root stock of pomato plant

\begin{tabular}{|c|c|c|}
\hline Plant no. & Number of tubers per plant & total weight of tuber per plant $(\mathbf{g})$ \\
\hline $\mathbf{1}$ & 3 & 222.50 \\
\hline $\mathbf{2}$ & 4 & 208.00 \\
\hline $\mathbf{3}$ & 3 & 214.00 \\
\hline $\mathbf{4}$ & 4 & 206.50 \\
\hline $\mathbf{5}$ & 5 & 206.00 \\
\hline $\mathbf{6}$ & 4 & 214.00 \\
\hline $\mathbf{7}$ & $\mathbf{4}$ & 217.50 \\
\hline Average & $\mathbf{3 . 8 5}$ & $\mathbf{2 1 1}$ \\
\hline
\end{tabular}

The grafted plants produced profuse branches and flowers though depend upon graft compatibility, environmental condition, scion and rootstock relationship etc. Mature fruits of tomato were ready to start harvest in about 110 days after grafting and harvesting was continuing up to 150 days. After transplanting tomato plant generally required about 65 to 90 
days to produce marketable fruits but grafted plant took more time as the mineral nutrients from soil via root stock and photo-assimilates from scion was translocated in slowly due to two (tomato and potato) different pathways. So, it may cause against the more time taken. It was cleared that by applying this technique harvesting period of tomato can be enhanced. The rootstock-scion combination may change the hormonal behavior and influence on grafted organs to initiate the flower (Satoh, 1996). Flowering period also change the fruit harvesting period, which influences the quality of the fruits. The result also showed that average fruits per plant in tomato were 35 , fruit weight 78 gram and an individual plant produce about 2729.79 gram fruits. Tomato yield can be increased by applying grafting technique reported by Khah, et al., (2006); Kleinhenz et al., (2009) and Gebologlu et al., (2011). Soare et al., (2016) were also worked on tomato grafting using tomato cultivar 'Lorely F1' as a scion and 'Beaufort' as a rootstock and shown that it had a positive effect on vegetative growth and production and the highest production $(9.2 \mathrm{~kg}$ per plant) was achieved from variant 3grafted tomatoes plant pruned with two stems. The present study also recorded that edible potato tubers were ready to harvest at 120 days after grafting and yielding about 4-5 number of potato around 211 gram tuber from each plant. Yield of potato was low but it creates a scope to research on improvement of potato yield from pomato. Photo-assimilate circulated by tomato scion to potato rootstock was less as compared to scion, this may cause the lower yield of potato.

In conclusion, grafting between tomato and potato plant was successful and produced fruits at aerial parts and tuber in underground portion from a single plant of pomato. Grafting can influence the fruit harvesting period and quality. It may be suggested that any home gardener can practice this technique as an amazing satisfaction which may fulfil home requirement to some extend for both tomato and potato. However, this report can give a land, labour and time saving tool to meet the extra demand of food by producing extra food from a single plant in the same time but it needs further study for commercialization in large scale.

\section{Acknowledgement}

The authors are thankful to the Director of Extension Education and all the personals of Dakshin Diinajpur KVK, Majhian, Uttar Banga Krishi Viswavidyalaya, Pundibari, West Bengal for their kind co-operation to conduct the present experiment.

\section{References}

Anonymous. 2018. Tomato. Monthly Report:, January, Horticulture Statistics Division, Department of Agriculture, Cooperation and Farmer's Welfare, Ministry of Agriculture and Farmer's Welfare, Government of India, New Delhi.

Anonymous. 2018. Potato. Monthly Report:, May, Horticulture Statistics Division, Department of Agriculture, Cooperation and Farmer's Welfare, Ministry of Agriculture and Farmer's Welfare, Government of India, New Delhi.

David, G. 2013. Tomato Is The Latest Wonderplant. NPR News. Retrieved 30.

Gebologlu N., Yilmaz E., Cakmak P., Aydin M. and Kasap Y. (2011), Scientific Research and Essays, vol. 6, no. 10, pp. 2147-2153.

https://en.wikipedia.org/wiki/Pomato https://www.zmescience.com/science/domesti c-science/tomtato-or-pomato-halfpotato-half-tomato-plant-increasescrop-efficiency/

https://www.netafim.co.za/offering/irrigation/ agriculture/field/potato/ $\mathrm{id}=80$ 
http://agritech.tnau.ac.in/banking/PDF/Tomat o.pdf

Khah E.M., Kakava E., Mavromatis A., Chachalis D. and Goulas, C. 2006. Journal of Applied Horticulture, vol. 8, no. 1, pp. 3-7.

Kleinhenz D.M., Francis D. M., Young M. and Aldrich T. 2009. Rootstock Effects on Yield of Grafted Celebrity' Tomato in Ohio. Ohio Agricultural Research and Development Center (OARDC). The Ohio State University.

Kubota, C., Kokalis-Burelle, M. A. M. N., Bausher, M. G. and Rosskopf E. N. October 2008.Vegetable Grafting:
History, Use, and Current Technology Status in North America, Hort Science., vol. 43, no. 6, pp. 1664-1669.

Reinhard, R. 2008. Biotechnology for Beginners. Elsevier., pp. 210.

Satoh, S. (1996), "Inhibition of flowering of cucumber grafted on rooted squash stocks". Physiol. Plant. vol. 97, pp. 440-444.

Soare, R., Maria, D. and Cristina, B. 2016. The effect of using grafted seedlings on the yield and quality of tomatoes grown in greenhouses. Horticultural Science. 45(2), 76-82.

\section{How to cite this article:}

Siddikul Islam, Sk Isa Hoque, Suchand Datta, Ranjit Chatterjee and Prahlad Sarkar. 2019. Pomato: Double Harvest from a Single Plant. Int.J.Curr.Microbiol.App.Sci. 8(04): 2026-2030. doi: https://doi.org/10.20546/ijcmas.2019.804.237 